De Bonnet's philosophical theories were largely influenced by the time in which he lived; he wrote a work on the "Proofs of Christianity" to defend Revelation, and valiantly opposed the teachings of Voltaire and Rousseau, and the epigenesis theory of Buffon. On the other hand, he advanced the purely materialistic idea that all thought is due to vibrations of the nerves. Bodily activity, he said, is a necessary condition of thought.

Following Cuvier and Leibnitz in the doctrine of original creation by a Deity, de Bonnet then premised a "germ" of perfecting evolution in every living thing. In his "Contemplation of Nature," he taught that all beings in nature form a graduated and unbroken scale from lowest to highest, with no gaps from the lowest atom of matter to "Archangels"; though the flaw in his perfectability theory appears when he denies that the highest of his heirarchy can ever exactly equal Deity itself. In "Philosophic Palingenesis," he elaborated this doctrine to show the survival not merely of man, but of all animals, and the perfecting of their faculties in the future state. Man, he said, is composed of a material body and an immaterial mind, resident in his brain; but he carries within himself the germ of a more attenuated body which will clothe his mind in the next stage after life on earth-a curious approximation to some of the teachings of modern Spiritualism. What he does not make clear is whether he expects each individual to carry within himself the germ of his own perfectability, or whether it is only races of men and kinds of animals that are perfected en masse.

De Bonnet's philosophy is chiefly interesting as a commentary on his scientific attainments. If he had died at twenty-five, he would have left his most valuable achievements already accomplished; but if, two hundred years ago, he had never been born, the world of science even to-day would have been a great deal the loser.

Maynard Shipley

\section{SCIENTIFIC EVENTS}

\section{THE PRESERVATION OF NATURAL CONDITIONS}

For three years the Ecological Society of America has had a committee composed of about twenty-five interested persons, investigating the question of preserving natural conditions for scientific study. The work to date has been concerned with (a) listing and describing preserved areas and areas desirable for reservation, (b) determining the policies governing existing reservations and the desirability of reserving natural areas within them, (c) collecting arguments in favor of preserves, $(d)$ determining lines of research and education, scientific, artistic and historical which require or can make use of reservations, and $(e)$ methods which have been successfully employed in securing reservations. The matter in hand includes a list of more than six hundred areas in United States and Canada which are preserved or are desirable for preservation. It is evident that some types of natural conditions are not represented and for some localities no areas have been brought to our attention. Persons having information regarding areas desirable for preservation or already preserved or knowledge concerning any of the subjects noted above, especially methods employed in securing reservations, are requested to send information, which will be fully credited, to the chairman or any member of the committee. The present committee is composed of C. W. Alvord (history), Univ. of Ill.; H. C. Cowles (plant communities), Univ. of Chicago; R. T. Fisher (forest practice), Harvard Univ.; S. A. Forbes (entomology), Univ. of Ill., A. S. Pearse (aquatic preserves), Univ. Wis., C. F. Korstian (grazing), Ogden, Utah; R. B. Miller (forest laws), Univ. of Ill.; T. C. Stephens (bird preserves), Sioux City, Ia.; R. H. Wolcott (fires), Univ. of Nebr.; F. B. Sumner, La Jolla, California; M. J. Elrod, Univ. of Mont.; F. J. Lewis, Univ. of Alberta; John Davidson, Univ. of Br. Columbia; G. B. Rigg, Univ. of Washington; F. Ramaley, Univ. of Colo.; G. A. Pearson, Flagstaff, Ariz.; G. W. Goldsmith, Univ. of Nebr.; J. R. Watson, Univ. of Fla.; J. W. Harshberger, Univ. of Pa.; W. L. Bray, Syra- 
cuse Univ.; C. D. Howe, Univ. of Toronto; F. E. Lloyd, McGill Univ.; C. O. Rosendahl, Univ. of Minn.

V. E. Shelford, Chairman

UNIVERSITY OF ILLINOIS

\section{THE NATIONAL COMMITTEE ON MATHE-} MATICAL REQIREMENTS

AT the last meeting of the General Education Board in New York on February 28, the sum of $\$ 25,000$ was appropriated for the use of the National Committee on Mathematical Requirements to continue its work for the year beginning July 1, 1920.

A preliminary report on "The Reorganization of the First Courses in Secondary School Mathematics" was published for the Committee by the U. S. Bureau of Education about the middle of February. It has been distributed widely. Copies of the report have gone to all the state departments of education, to all county and district superintendents in the United States and to all city superintendents in cities and towns of over 2,500 population. It has been sent to all the normal schools in the country, to some 1,500 libraries and to almost 300 periodicals and newspapers. In addition it has been sent to about 4,500 individuals, the names and addresses of which were furnished the Bureau of Education by the National Committee. This list of individuals consists chiefly of teachers of mathematics and principals of schools throughout the country. Additions to this mailing list to secure future copies of the reports of the committee can still be made. Individuals interested in securing these reports should send their names and addresses to the chairman of the committee (J. W. Young, Hanover, N. H.).

A subcommittee consisting of Professor C. N. Moore, of the University of Cincinnati, Mr. W. F. Downey, of Boston, and Miss Eula Weeks, of St. Louis, has been appointed to prepare a report for the Committee on Elective Courses in Mathematics for Secondary Schools. Any material or suggestions for this report may be sent directly to the chairman of the subcommittee.

The recent work of the national committee had a place on the program of the organization meeting of the National Council of Teachers of Mathematics held in Cleveland on February 24 in connection with the meeting of the Department of Superintendence of the National Education Association. The meeting for the organization of the National Council was enthusiastically attended. A constitution was adopted and officers and an executive committee elected. Mr. J. A. Foberg, of the National Committee on Mathematical Requirements, was elected secretary-treasurer of the National Council.

Recent meetings of teachers at which the reports of the national committee have been discussed have taken place in New York City, Cincinnati, San Francisco, Cleveland, Oklahoma, Philadelphia, Springfield (Mass.), Providence (R. I.). Meetings in April will take place in Alabama, Illinois, Iowa, Michigan and Kentucky.

\section{THE NEW YORK STATE COLLEGE OF AGRICUL- TURE AND THE NEW YORK STATE EXPERIMENT STATION}

The State College of Agriculture at Ithaca and the State Agricultural Experiment Station at Geneva have now become formally affiliated. Each will retain its separate organization and carry on its own appropriate work; in addition provision is made for somewhat closer correlation, for ready exchange of all facilities of research and experimentation, and for more frequent conferences. To these ends the trustees of Cornell University have appointed to the staff of the college eight persons on the staff of the station at Geneva: Whitman H. Jordan, director; R. J. Anderson, chemist; Robert S. Breed, bacteriologist; R. C. Collinson, chemist; U. P. Hendrick, horticulturist; Percival J. Parrott, '06, entomologist; Fred C. Stewart, '98, botanist; and L. L. Van Slyke, specialist in fertilizers. And reciprocally the board of control has appointed to the Geneva staff six members of the agricultural faculty: Professors Chandler, Emerson, Herrick, Lyon, Reddick, and Stocking.

The Cornell Alumni Weekly says: "This closer relationship promises benefits not only to the college, particularly in enlarging the 